\title{
Loss of testate amoeba functional diversity with increasing frost intensity across a continental gradient reduces microbial activity in peatlands
}

Vincent E.J. Jassey ${ }^{a, b, *}$, Mariusz Lamentowicz ${ }^{c}$, Luca Bragazza ${ }^{a, b, d}$, Maaike L. Hofsommer $r^{a, b, e}$, Robert T.E. Mills ${ }^{a, b, g}$, Alexandre Buttler ${ }^{a, b, f}$, Constant Signarbieux ${ }^{a, b}$, Bjorn J.M. Robroek ${ }^{a, b}$

aÉcole Polytechnique Fédérale de Lausanne (EPFL), School of Architecture, Civil and Environmental Engineering (ENAC), Laboratory of Ecological Systems (ECOS), Bâtiment GR, Station 2, CH-1015 Lausanne, Switzerland

${ }^{b}$ WSL - Swiss Federal Institute for Forest, Snow and Landscape Research, Site Lausanne, Station 2, Case postale 96, CH-1015 Lausanne, Switzerland

${ }^{\mathrm{C}}$ Laboratory of Wetland Ecology and Monitoring, Faculty of Geographical and Geological Sciences, Adam Mickiewicz University, Dzięgielowa 27, 61-680 Poznań, Poland

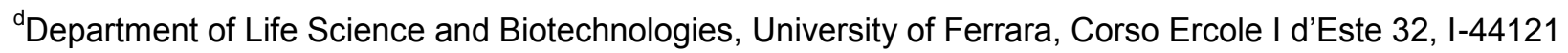

Ferrara, Italy

${ }^{\mathrm{e}}$ Ecology and Biodiversity Group, Institute of Environmental Biology, Faculty of Science, Utrecht University, Padualaan 8, $3585 \mathrm{CH}$ Utrecht, The Netherlands

fUniversité de Bourgogne Franche-Comté, UMR CNRS 6249 Chrono-Environnement, 16 route de Gray, F25030 Besançon cedex, France.

${ }^{9}$ Current address:

Lancaster Environment Centre, Lancaster University, Lancaster, LA1 4YQ, United Kingdom

*Corresponding author; phone: +41 (0) 2169339 06; fax: +41 (0) 216933913

E-mail address: vincent.jassey@epfl.ch (V.E.J. Jassey) 


\begin{abstract}
Soil microbial communities significantly contribute to global fluxes of nutrients and carbon. Their response to climate change, including winter warming, is expected to modify these processes through direct effects on microbial functions through osmotic stress, and changing temperature regimes. Using four European peatlands reflecting different frequencies of frost events, we show that peatland testate amoeba communities diverge among sites with different winter climates, and that this is reflected through contrasting functions. We found that exposure to harder soil frost promoted species $\beta$-diversity (species turnover) thus shifting the community composition of testate amoebae. In particular, we found that harder soil frost, and lower watersoluble phenolic compounds, induced functional turnover through the decrease of large species ($68 \%,>80 \mu \mathrm{m})$ and the increase of small-bodied mixotrophic species (i.e. Archerella flavum; $+79 \%)$. These results suggest that increased exposure to soil frost could be highly limiting for large species while smaller species are more resistant. Furthermore, we found that $\beta$-glucosidase enzymatic activity, in addition to soil temperature, strongly depended ( $R^{2}=0.95$, ANOVA) of the functional diversity of testate amoebae. Changing winter conditions can therefore strongly impact peatland decomposition process, though it remains unclear if these changes are carried-over to the growing season.
\end{abstract}

Keywords: Beta-diversity; Enzymatic activity; Functional turnover; Mixotrophy; Phenolic compounds; Winter climate change 


\section{Introduction}

Global climate is changing, and while substantial research effort seeks to understand the effects of increasing temperatures in summer (Stocker et al., 2014), winter warming, which is comparatively understudied, could be more crucial for key ecosystem processes (Bjerke et al., 2011; 2013; Kreyling, 2010; Kreyling et al., 2011). Winter climatic conditions are indeed changing in many parts of the world, thereby contributing to altering the structure and function of terrestrial ecosystems (Cornelissen and Makoto, 2014; Makoto et al., 2014). Many ecosystems from midhigh latitude are seasonally snow-covered and hence protected against freeze-thaw cycles during the winter. However, as a result of increased winter temperatures, snow cover is significantly declining by c.a. $31,000 \mathrm{~km}^{-2} \cdot \mathrm{y}^{-1}$ on average from 1930 to 2005 (Hooper et al., 2013), leaving the vegetation and soil exposed to frost events (Groffman et al., 2001). Although impacts of winter climate change on plants has been confirmed by a number of observations (Bokhorst et al., 2008; 2009; 2015; Hollesen et al., 2015), its effect on soil microbes remains overlooked, despite the potential for drastic modifications of biogeochemical processes (Bokhorst et al., 2010; Durán et al., 2013; 2014; Robroek et al., 2013).

In northern peatlands, testate amoebae (protozoa) play an important functional role both in C mineralization and C assimilation (Lamentowicz et al., 2013; Jassey et al., 2015). As predators of bacteria and fungi (Gilbert et al., 2003; Wilkinson and Mitchell, 2010; Jassey et al., 2012) they indirectly influence decomposition rates and thus represent a key trophic link between organic matter cycling, decomposers, mesofauna and plants (Ledeganck et al., 2003; Krashevska et al., 2014; Mieczan et al., 2015b). Furthermore, a recent study highlighted that mixotrophic testate amoebae (i.e. species combining predation and photosynthesis) can significantly contribute to the net $\mathrm{C}$ fixation in peatlands (Jassey et al., 2015). Short generation times and large population sizes enable testate amoebae to cope with the harsh winter season (Beyens et al., 1986; Beyens, 1989; Vincke et al., 2004), but decreasing snow cover and repeated exposure to cold temperatures are also costly in terms of development and survival (Bale, 2002). It has been shown that fluctuations in snow depth decreased testate amoeba diversity altering their community composition (Tsyganov et al., 2012). In this context, an important question is whether a decrease in testate amoeba richness/diversity reduces their functional diversity, i.e. the extent of functional differences among 
the species in a community (= functional alpha diversity), and whether variation in species composition in response to harder soil frost influences their functional turnover (i.e. functional beta diversity). If species share the same functional traits, redundancy in the community dampens the potential negative consequences of species loss for functional diversity, and hence for ecosystem processes (Fonseca and Ganade, 2001). However, if some species with specific traits are lost or gained from the community, functional diversity may change (i.e. the community host different functional strategies), therefore leading to cascading effects on ecosystem processes (Villéger et al., 2013). Indeed, beyond the changes in species richness and/or composition, modifications of functional diversity may have far-reaching consequences (Milcu et al., 2014; Perkins et al., 2015). Forecasting the changes in species (functional) diversity under different climatic conditions in winter is thus an urgent topic which will help our understanding of climate change effects on peatland functioning, including microbial interactions (e.g. predation) and related biogeochemical processes.

Here we test whether testate amoeba functional diversity (functional alpha- and betadiversity) differs among four European Sphagnum-dominated peatlands experiencing different amount of frost events due to prevailing winter conditions. We characterized testate amoeba functional diversity using a set of six morphological traits associated with their trophic role and feeding habit (see methods). As warmer winter temperatures have been shown to shift microfauna toward larger and heavier organisms (Bokhorst et al., 2012), we hypothesized (1) that snow insulation effect will favour survival of testate amoeba with a large body size. Given that reduced snow-cover will expose testate amoebae to an increasing of frost events, we further hypothesised that this (2) will stress the community (e.g. more encysted species, lower species richness, and/or smaller species). These changes will ultimately impact on testate amoeba community composition and functional diversity, resulting in (3) changes in biogeochemical processes such as microbial hydrolytic enzyme activity. 


\section{Materials and Methods}

\section{Study sites and sampling}

We selected four sites along an oceanic-continental gradient: Clara, Forbonnet, Kusowo and Store Mosse (Fig. 1). Clara $\left(53^{\circ} 19^{\prime} \mathrm{N}, 07^{\circ} 37^{\prime} \mathrm{W}, 58 \mathrm{~m}\right.$. a.s.I) is an open bog situated in the Irish midlands. Sphagnum magellanicum was the most abundant peat moss species, whilst $S$. cuspidatum, S. rubellum and S. fuscum co-occurred. Rhynchospora alba, Vaccinium oxycoccus, Andromeda polifolia and Menyanthes trifoliata were the most common vascular plant species at the sampling location in Clara. Forbonnet is an ombrotrophic peatland situated in the Jura Mountains of France $\left(46^{\circ} 49^{\prime} 35^{\prime \prime} \mathrm{N}, 6^{\circ} 10^{\prime} 20^{\prime \prime} \mathrm{E}, 840 \mathrm{~m}\right.$ a.s.l). The moss carpet was co-dominated by Sphagnum fallax and S. magellanicum while the field layer was dominated by Eriophorum vaginatum, A. polifolia, V. oxycoccus and Carex rostrata. Store Mosse is an ombrotrophic peatland in the Store Mosse National Park, Southern Sweden $\left(57^{\circ} 17^{\prime} \mathrm{N}, 14^{\circ} 00^{\prime} \mathrm{E}, 166 \mathrm{~m}\right.$ a.s.I). $S$. magellanicum dominated the moss layer whereas. E. vaginatum, Calluna vulgaris, A. polifolia, Empetrum nigrum, V. oxycoccus and Erica tetralix dominated the vascular plant layer. Kusowkie Bagno (Kusowo) is a bog located in northern Poland (5348'28” N, 16³5'14” E, 150 m a.s.l; Fig. 1) in a nature reserve and is part of the Special Area of Conservation Natura 2000 site "Lake Szczecineckie" (PLH 320009). The moss layer was dominated by S. magellanicum while Drosera rotundifolia, V. oxycoccus, E. vaginatum and Carex limosa characterized vascular plant vegetation.

Samples were collected within the same week in early-February 2014 as representative of mid-winter conditions (Fig. 1). In each site, we chose five homogeneous Sphagnum magellanicum patches $(20 \times 20 \mathrm{~cm}$, separated at least $5 \mathrm{~m}$ from each other to take into account heterogeneity in the microbial communities (Mitchell et al., 2000)). Sphagnum magellanicum was chosen because it was the most common Sphagnum species in all the sites. Only Sphagnum patches with a vascular plant cover lower than $10 \%$ were chosen to avoid as much as possible any effect of vascular plants on microbial assemblages and processes (Robroek et al., 2015). We collected samples for testate amoebae, enzymatic activities and water-soluble phenols within the living portion of Sphagnum magellanicum $(0-5 \mathrm{~cm}$, including the capitula). Climatic variables (air and soil temperature, precipitation) were continuously monitored (every 30 minutes) on site at Forbonnet (Forbonnet Scientific Research station) and Store Mosse (Store Mosse Research station). For 
Kusowo and Clara, we used climatic data from the closest meteorological stations (Szczecinek and Mullingard meteorological stations, respectively; data on a daily basis). In all the study sites, snow height was measured during sampling.

\section{Testate amoeba analyses and functional space calculations}

We collected $10 \mathrm{~g}$ of fresh Sphagnum magellanicum shoots $(10 \mathrm{~g} \mathrm{f} . \mathrm{wt}, 0-5 \mathrm{~cm}$ from the capitulum) in each plot to analyse testate amoeba diversity and community composition. Samples were fixed in $20 \mathrm{~mL}$ glutaraldehyde ( $2 \%$ final concentration) immediately after sampling and stored at $4^{\circ} \mathrm{C}$ in dark conditions. Testate amoebae were extracted from fixed samples following the method described in Jassey et al. (2011b). Testate amoebae were identified at species level by inverted microscopy (x200 and x400; LEICA DMIL) following Utermölh's method (Utermolh, 1958). A minimum of 150 individuals was reached to achieve relevant species diversity (Payne and Mitchell, 2009). Living and encysted individuals were taken into account. Next, we compiled six functional traits (Table 1) to characterize the functional space (i.e. a multidimensional space where axes are functional traits along which species are placed according to their functional trait values; (Villéger et al., 2011) of each testate amoeba species: mixotrophy/heterotrophy, biovolume, biomass, body length, diameter of the pseudostome (shell aperture) and body range. Each trait was measured under the microscope for each sample to take into account species-trait plasticity, especially for body size measurements. The biomass was estimated by converting the total biovolume of each species (biovolume $x$ density) into $C$ using the standard conversion factor: 1 $\mu \mathrm{m} 3=1.1 \times 10^{-7} \mu \mathrm{gC}$ (Gilbert et al., 1998). Community Weighted Means (CWM) for each trait were calculated as abundance weighted means of species trait values (Garnier et al., 2007).

Per species, we constructed a functional space. We first created a functional distance matrix by applying Gower's distance on each pair of species described by their traits, and then computed a Principal Coordinate Analysis (PCoA) on it. Gower's distance allows mixing of different types of traits (i.e. qualitative and quantitative traits) while giving them equal weights. Then, the first four axes of the PCoA were selected as synthetic functional traits summarizing testate amoeba functional space, and species coordinates in the four-dimensional space defined by the 
PCoA were used to calculate functional metrics as synthetic functional trait values (Villéger et al., 2008).

Measuring taxonomic and functional alpha diversity of testate amoebae

Testate amoeba taxonomic alpha diversity was calculated using Simpson's diversity index. Functional alpha diversity (FD) of communities was calculated using the Rao quadratic entropy $(Q)$ index (Ricotta, 2005):

$\mathrm{FD}_{\mathrm{Q}}=\sum_{i j}^{S}$ dijpipj

where $d i j$ is the functional difference between the $i$-th and $j$-th species ( $d i j=d j i$ and $d i i=0)$, and $p i$ and $\mathrm{p} j$ the relative contribution of species $i$ and $j$ to the abundance of the whole testate amoebae community. dij was calculated as the Gower's distance on each pair of species described by their traits. $\mathrm{FD}_{\mathrm{Q}}$ permits the measurement of the diversity of a given community by combining the species relative abundances described by their functional traits. $F D_{Q}$ is unitless, and shows how communities are functionally different, i.e. increasing $\mathrm{FD}_{\mathrm{Q}}$ values indicate functionally increasingly different communities. $F D_{Q}$ was calculated in the $R$ statistical environment ( $R$ Core Team, 2013) using the FD package (Villéger et al., 2008).

\section{Taxonomic and functional beta diversity in testate amoeba assemblages}

For each of the 190 pairs of testate amoeba communities, taxonomic and functional $\beta$ diversity and their turnover and nestedness-resultant components were computed following Villéger et al. (2013). Taxonomic $\beta$-diversity is defined as the percentage of dissimilarity in species composition between two communities; it equals 0 when two communities are identical in species composition and 1 when the two communities share no species (dissimilar communities). Taxonomic $\beta$-diversity can be influenced by species richness; if a certain community has a much larger number of species than another community, taxonomic $\beta$-diversity (dissimilarity) between these two communities is close to its maximum value (Baselga, 2010). Therefore, taxonomic $\beta$ diversity is defined as the sum of a turnover component (i.e. species replacement in the two communities) and a nestedness-resultant component (i.e. difference in number of species between the two communities compared). Taxonomic turnover and nestedness-resultant components also 
vary between 0 and 1 . Taxonomic turnover equals 0 when community $A$ hosts the same subset of species than community $B$, while taxonomic nestedness equals zero when the two communities have the same number of species (more details can be found in Baselga (2010).

As for taxonomic $\beta$-diversity, functional $\beta$-diversity equals 0 when two communities are functionally similar (same functional traits can be found; functionally similar communities) and it equals 1 when the two communities share different functional traits (functionally dissimilar communities). A high level of functional $\beta$-diversity can result from a high value of functional turnover (i.e. the communities host species with different functional strategies) or a low value of functional turnover (community A hosts a small subset of the functional strategies in community B), in this case the functional nestedness-resultant component is high (i.e. a community fills only a small portion of the functional space filled by the other community; for further details see Villéger et al. (2013). Taxonomic and functional $\beta$-diversity and their respective turnover and nestednessresultant components were performed in $R$ with codes adapted from the betapart $R$ package (Baselga and Orme, 2012).

Enzymatic activities, water-soluble polyphenols and pore water analyses

We used substrates labelled with the fluorophores 7-amino-4-methylcoumarin (MUC) or methylumbelliferone (MUB) to quantify the relative activity (i.e. enzyme activity under saturating substrate conditions) of enzymes responsible for the hydrolysis of one peptide (L-alanine-7-amidoMUC, Alanine), one carbohydrate (4-MUB- $\beta$-glucopyranoside, $\beta$-glucosidase) and one phosphate ester (4-MUB-phosphate, phosphatase; all substrates supplied Sigma-Aldrich Switzerland) (Weedon et al., 2014). Enzymes were extracted following Jassey et al. (2011a) and analysed in microplates. For each sample, 4 pseudo-replicate wells were included in a 96 well microtiter plate. Assay wells received $38 \mu \mathrm{L}$ of extract and $250 \mu \mathrm{L}$ of enzyme substrate. For each sample, 4 pseudo-replicate wells containing $38 \mu \mathrm{L}$ of boiled extract $\left(3 \mathrm{~h}\right.$ at $\left.90^{\circ} \mathrm{C}\right)$ were performed as a control. Then microplates were incubated at $25^{\circ} \mathrm{C}$ for $3 \mathrm{~h}$. Fluorescence was monitored spectrophotometrically with an excitation wavelength of $365 \mathrm{~nm}$ and emission detection at $450 \mathrm{~nm}$ (Biotek, SynergyMX). All measurements were converted to nanomoles per gram dry weight per $\min \left(\mathrm{nmol} \cdot \mathrm{min}^{-1} \cdot \mathrm{g}^{-1} \mathrm{DM}\right)$. 
We quantified Sphagnum water-soluble phenolics as a potential environmental driver of testate amoeba communities. Indeed bryophytes, and especially their phenolic compounds, can be a major driver of testate amoeba community composition (Jassey et al., 2011b; 2014). For moss water-soluble phenolics, $0.05 \mathrm{~g}$ dry weight (DW) of $S$. magellanicum was grinded in a mortar, mixed with $10 \mathrm{~mL}$ distilled water, bubbled with nitrogen and agitated on a reciprocal shaker (150 rpm) for 3 hours and filtered (Jassey et al., 2011b). Water-soluble phenolics were quantified with the Folin-Ciocalteau reagent and were expressed in mg equivalent gallic acid $\left(A_{760}\right)$.

\section{Statistical analyses}

We performed a redundancy analysis (RDA) to relate climatic variables (air and soil temperatures, precipitation, snow height) to testate amoeba species composition and CWM traits composition. The testate amoeba data set was preliminary Hellinger-transformed (Legendre and Gallagher, 2001) while CWM traits were standardized. Stepwise selection among the climate variables was computed using the 'ordistep' function available in the vegan $R$ package (Oksanen, 2011). This stepwise selection was achieved using AIC (Akaike Information Criterion) and permutation tests. We assessed and tested the spatial dependence of testate amoeba community structure by means of direct multiscale ordination (MSO) applied on the results of the RDA. MSO is a geostatistical tool allowing for spatial partitioning of community variation among distance classes and testing of the spatial community structure (Wagner, 2004). Spatial independences were assessed by means of Mantel test (999 permutations). The 'grain' (i.e. interval size for distance classes) of the variogram was chosen as the truncation threshold (i.e. the longest distance in the minimum spanning tree of the spatial matrix) from a Principal Coordinates of Neighbourhood Matrix (PCNM) analysis applied on the site coordinates (Borcard et al., 2011).

Linear mixed effect models were used to determine whether testate amoeba species richness, diversity, biomass and $\mathrm{FD}_{\mathrm{Q}}$ varied among sites (fixed effect) while accounting for repeated measurements within each site. All models included site as a random effect on the intercept, as to correct for the inflation of the residual degrees of freedom that would occur if we were using repeated measurements within sites as true replicates (Pinheiro and Bates, 2000). Similar tests were used for enzymes and phenols. The correlation between taxonomic $\beta$-diversity 
components and winter climatic dissimilarity between peatlands were tested using Mantel permutational tests. Similar tests were used with functional $\beta$-diversity components. Winter climatic dissimilarity was defined as the pairwise Euclidean distance between two peatlands in terms of minimum air temperature, mean winter air and soil temperatures, snow height and precipitation. All computations were performed in R 3.0.1 (R Core Team 2013).

\section{Results}

Climatic conditions in the four peatlands

Winter climatic conditions at Clara bog between first of January and early-February 2014 were very wet $(301 \mathrm{~mm})$ and relatively warm with mean air and soil temperature of $4.3^{\circ} \mathrm{C}$ (minimum air temperature $=-4.3^{\circ} \mathrm{C}$ ) and $4.7^{\circ} \mathrm{C}$, respectively (Fig. 1). At Forbonnet, they were wet $(184 \mathrm{~mm})$ and relatively cold with mean air and soil temperatures of $1.7^{\circ} \mathrm{C}$ (minimum air temperature $=-11.9^{\circ} \mathrm{C}$ ) and $1.9^{\circ} \mathrm{C}$, respectively. The moss layer was covered by $6 \mathrm{~cm}$ of snow, which had been present for several weeks (Fig. 1). In Store Mosse, the conditions were relatively wet $(127 \mathrm{~mm})$ and cold with mean air and soil temperatures of $-0.5^{\circ} \mathrm{C}$ (minimum air temperature $=$ $10.7^{\circ} \mathrm{C}$ ) and $-0.4^{\circ} \mathrm{C}$, respectively. In Kusowo, winter climatic conditions were very dry (21 $\left.\mathrm{mm}\right)$ and cold with mean air and soil temperatures of $-1.3^{\circ} \mathrm{C}$ (minimum air temperature $=-16.9^{\circ} \mathrm{C}$ ) and $0.5^{\circ} \mathrm{C}$, respectively. At sampling, S. magellanicum was covered by less than $1 \mathrm{~cm}$ of snow. Winter climatic dissimilarity analysis, using Kusowo as a reference for pairwise comparisons (highest longitude), showed that a gradient of winter climatic conditions paralleled the longitudinal gradient. Kusowo was closer to Store Mosse $(d=2.01)$ than to Forbonnet $(d=3.79)$ and Clara $(d=4.78$; Fig. 1). Differences in temperatures and amount of precipitation mainly explained such (dis)similarities (Fig. 1).

To test whether our climatic data recorded in each site from beginning of January to midFebruary were representative of global winter climatic conditions, we compared these data to global climatic data available in the WorldClim database (Hijmans et al., 2005), i.e. minimum temperatures, mean winter temperature and precipitations. We found strong correlations between our data and those from WorldClim (minimum temperature: $r=0.91, P<0.001$; mean winter air 
temperature: $r=0.94, P<0.001$; precipitation $r=0.80, P<0.001$ ), which validated our meteorological data as representative of winter climatic conditions for each site.

Variations of water-soluble polyphenols in the different European peatlands

Water-soluble phenolic compounds significantly differed along the gradient $\left(F_{1,3}=8.4, P=\right.$ 0.003). Water-soluble phenolics showed lower values in Kusowo and Store Mosse and higher values in Forbonnet (Table 2). We further found that water-soluble phenolic compounds increased with rising temperatures, precipitation and snow cover depth (Supplementary Table 1).

\section{Relationships between testate amoeba communities and winter conditions}

Redundancy analysis (RDA) showed clear patterns of testate amoeba species composition along the gradient (Fig. 2A). The best RDA model selected four explanatory variables, which together explained $67.1 \%$ of the variance (adjusted $R^{2}$ ). Analysis of the ordination space (first two axes were significant at $P<0.001$ ) showed that testate amoeba communities aggregated into three groups: Forbonnet, Kusowo and Store Mosse/Clara bogs. Forbonnet group was characterized by a domination of Nebela species (N. tincta, N. collaris, and N. militaris) while Kusowo group was dominated by Heleopera sphagni, Hyalosphenia papilio and Phryganella species (Fig. 2A). High abundance of Archerella flavum and Assulina muscorum characterized the Store Mosse/Clara group. These three groups were related to snow depth $\left(F_{1,15}=18.6, P=0.001\right)$, precipitations (Wprec; $\left.F_{1,15}=6.2, P=0.002\right)$, minimum temperature (TMIN; $\left.F_{1,15}=5.5, P=0.002\right)$ and Sphagnum water-soluble phenolics (phenols; $F_{1,15}=12.5, P=0.001$ ). On the first RDA axis, the thicker snow cover and higher amount of phenolics in Forbonnet, as compared to the other bogs, explained the differences in testate amoeba species composition at Forbonnet. On the second axis, peatlands are spread along the temperature gradient, and to a lesser extend along the precipitation gradient (Fig. 2A). The variogram from the MSO (Fig. S1) showed no clear pattern of testate amoeba community structure with distance and no significant autocorrelation was found in any distance class. Species composition from a site was thus spatially independent from a neighbouring site (e.g. Sweden vs. Poland). The MSO also showed that species-environment 
relationships were scale invariant and that gradients of temperature, precipitation and snow height were the main drivers of testate amoeba species composition.

In parallel to shifts in species composition, we also found clear patterns of CWM traits of testate amoebae using a redundancy analysis (Fig. 2B). The best RDA model selected two explanatory variables, which together explained $67.2 \%$ of the variance (adjusted $R^{2}$ ). Along the first axis $\left(F_{1,17}=37.9, P=0.001\right)$, CWM traits of testate amoeba communities aggregated into two groups: Forbonnet and Clara/Store Mosse/Kusowo. Snow cover in Forbonnet mainly explained this grouping $\left(F_{1,17}=33.9, P=0.001\right)$. Large species (high body length, biovolume, biomass and pseudostome size) characterized the testate amoeba community at Forbonnet while smaller species were in the other bogs (Fig. 2B). In particular, we found that large species decreased by $68 \%$ with increasing exposure to frost (no snow and cold soil temperatures), while smaller species increased by $79 \%$. The second axis $\left(F_{1,17}=3.1, P=0.02\right)$ is characterized by the gradient of freezing temperature (TMIN; $\left.F_{1,17}=7.1, P=0.004\right)$, with in order Clara, Store Mosse/Forbonnet, and Kusowo. The gradient of temperature is strongly related to the body range and mixotrophy traits of testate amoebae (Fig. 2B). Furthermore, the proportion of active individuals (non-encysted individuals) strongly decreased with warmer air and soil temperatures or higher snow depth (Supplementary Table 2). The higher proportion of encysted specimens was found in Kusowo (84\%) and Store Mosse (51\%), and the lower in Forbonnet (22\%) and Clara (31\%).

Species richness, species diversity, and functional diversity aspects of testate amoebae communities

We identified 36 testate amoeba species in the four study sites. Testate amoeba species richness (N0) and Simpson's diversity (N1) were significantly higher in Forbonnet bog (N0 = 18 and $\mathrm{N} 1=7.6$, respectively) compared to the other bogs (on average $\mathrm{N} 0=11, \mathrm{~N} 1=3.7$ ). Thicker snow cover in Clara, Kusowo and Store Mosse mostly explained such patterns (N0: $r=0.82, P<$ $0.01 ; \mathrm{N} 1: r=0.64, P<0.01)$. Taxonomic turnover contributed to $82 \%( \pm 14 \%)$ of taxonomic $\beta$ diversity (Fig. 3A x-axis), while nestedness-resultant component represented only $18 \%( \pm 16 \%$; Fig. 3B x-axis). Furthermore, taxonomic $\beta$-diversity significantly increased with winter climatic dissimilarity (Mantel test, $r=0.64, P<0.01$, Fig. 3C) due to taxonomic turnover rather than 
taxonomic nestedness-resultant component. More specifically, we found that taxonomic turnover increased with winter climatic dissimilarity (Mantel test, $r=0.57, P<0.01$, Fig. 3E) while taxonomic nestedness-resultant component not (Mantel test, $r=-0.017, P=0.48$ ).

Testate amoeba functional alpha diversity was the highest in Clara bog $\left(F D_{Q}=5.2\right)$, the lowest in Forbonnet $\left(F D_{Q}=4.0\right)$ and intermediate in Kusowo $\left(F D_{Q}=4.5\right)$ and Store Mosse $\left(F D_{Q}=\right.$ 4.3; $\left.F_{1,3}=20.1, P<0.001\right)$. Pearson's correlation tests showed that changes in $\mathrm{FD}_{\mathrm{Q}}$ were positively related to air and soil temperatures and negatively to snow depth (Supplementary Table 2). Functional turnover contributed on average to $62 \%( \pm 30 \%)$ of functional $\beta$-diversity (Fig. 3A yaxis), while functional nestedness-resultant component to $40 \%$ ( $\pm 35 \%$; Fig. 3B y-axis). Functional $\beta$-diversity was significantly correlated to winter climatic dissimilarity (Mantel test, $r=0.57, P<$ 0.01 , Fig. 3D) and on the whole, was very high $(0.74 \pm 0.02)$. Increasing functional $\beta$-diversity was related to the response of its functional turnover component $(0.46 \pm 0.024)$, which increased winter climatic dissimilarity (Mantel test, $r=0.39, P<0.01$, Fig. 3F). The response of its functional nestedness-resultant component $(0.28 \pm 0.013)$ was not related to winter dissimilarity (Mantel test, $r=-0.04, P=0.58)$.

\section{Relationships between testate amoeba functional diversity and microbial activity}

Only $\beta$-glucosidase activity responded to changing winter climatic conditions along the gradient $\left(F_{1,3}=4.1, P=0.03\right) . \beta$-glucosidase activity was higher in Clara bog (mean $1001 \pm 98 \mathrm{nmol} \mathrm{min}^{-1} \mathrm{~g}^{-}$ ${ }^{1} \mathrm{DM}$ ), lower in Kusowo (mean $485 \pm 88 \mathrm{nmol} \min ^{-1} \mathrm{~g}^{-1} \mathrm{DM} ; F=4.06, P=0.03$ ) and intermediate in Forbonnet $\left(866 \pm 153 \mathrm{nmol} \min ^{-1} \mathrm{~g}^{-1} \mathrm{DM}\right)$ and Store Mosse $\left(811 \pm 80 \mathrm{nmol} \min ^{-1} \mathrm{~g}^{-1} \mathrm{DM}\right)$. Here again, patterns of temperature, precipitation and snow cover depth mainly explained such changes in $\beta$-glucosidase activity (Supplementary Table 3$)$. Alanine peptidase $\left(F_{1,3}=0.62, P=0.61\right.$ ) and phosphatase $\left(F_{1,3}=1.83, P=0.19\right)$ activities did not change among sites (alanine peptidase: mean $=694 \pm 50 \mathrm{nmol} \mathrm{min}{ }^{-1} \mathrm{~g}^{-1} \mathrm{DM}$, phosphatase: mean $=4092 \pm 377 \mathrm{nmol} \mathrm{min} \mathrm{g}^{-1} \mathrm{DM}$; Table 2).

We further found a strong and significant positive relationship between functional $\beta$-diversity of testate amoeba communities and $\beta$-glucosidase activity $\left(R^{2}=0.95, P<0.01\right)$, while no relationship was found between testate amoeba functional alpha diversity and $\beta$-glucosidase activity $\left(R^{2}=0.10, P=0.68\right.$; Fig. 4$)$. Further analyses on traits variation revealed that shifts in the 
abundance of mixotrophs mainly explained the link between functional $\beta$-diversity of testate amoebae and $\beta$-glucosidase activity $\left(R^{2}=0.79, F_{1,2}=12.7, P=0.07 ; \mathrm{Fig} .4 \mathrm{~B}\right)$, while traits related to body characteristics had no significant influence $\left(R^{2}<0.1\right.$ and $P>0.7$ for all). No relationships were found between taxonomic alpha and $\beta$-diversity, neither with the activities of the other enzymes nor with functional alpha and $\beta$-diversity.

\section{Discussion}

Winter climate strongly influences testate amoeba communities

Deep soil freezing, fluctuations in soil moisture and exposure to strong frost events have been shown to significantly, but inconsistently, influence soil biological communities. Microfauna is usually highly sensitive to freezing soil temperatures because many taxa have no tolerance to freezing (Sømme, 1982; Cannon and Block, 1988; Konestabo et al., 2007). However, some studies also found no significant change in biomass, abundance and/or diversity of microfauna (Bokhorst et al., 2012). Furthermore, and despite these inconsistencies, shifts in soil microfauna communities in response to winter climate change have been poorly quantified at a functional level (but see Bokhorst et al., 2012). Here we show that freezing of the soil surface, exposure to frost (no snow cover) and lower precipitation led to high taxonomic and functional turnover in testate amoeba communities. This result indicates that species replacement in testate amoeba communities along the climatic gradient is mostly between species that are not functionally redundant (Villéger et al., 2013). We found that the presence of snow and/or mean soil temperatures higher than zero is crucial to maintain a high biomass and high functional diversity in testate amoeba communities. This corroborates previous findings of a maintenance or even an increase of testate amoeba density during long period of snow cover (Lousier and Parkinson, 1984). Interestingly, our results are opposite to recent observations in arctic tundra, where low density of active testate amoebae were found under a snow cover (Tsyganov et al., 2012). Snow in arctic tundra often establishes upon an already frozen soil, so considerably limiting the activity of soil protozoa during winter (Laminger, 1978), which probably explains such inconsistency. In accordance with our hypothesis, testate amoebae showed clear signs of stress with freezing conditions. Decreasing snow depth, low precipitations, and frozen soil strongly reduced testate 
amoeba activity by favouring cyst formation (+50\%, mostly large species). Freezing conditions also reduced the mean body size of the community (e.g. lower body length, biovolume and body range), as previously showed for Collembola (Bokhorst et al., 2012). Although testate amoebae are known to maintain metabolic activity with soil temperatures close to zero (Lousier and Parkinson, 1984), our results showed that freezing temperatures are highly limiting for large species activity and/or survival (e.g. Nebela sp., Heleopera sp. and Hyalosphenia sp.), while smaller species (e.g. Archerella flavum and Assulina muscorum) remain active and even replace the larger species. These results would indicate that the efficiency of energy transfer from lower to higher trophic levels required to maintain large individuals declined with frost and the decrease of large testate amoebae could be indirectly attributed to a decrease of their preys. However, we did not observe any change in the biomass of bacteria and fungi (Fig. S2), suggesting that changes in winter conditions had a direct effect on large testate amoebae.

In parallel to changes in winter climatic variables, our results revealed that moss chemistry (phenolics) also played a significant role in driving testate amoeba assemblages. While the production of phenolics is considered as an advantageous adaptive mechanism for plant protection against low temperatures (Dixon and Paiva, 1995; Martz et al., 2009), concentration of watersoluble phenolics decreased with low snow depth and low temperatures. Such contrasting results could either come from the phenolic compounds we targeted (i.e. water-soluble compounds instead of cell-bounded compounds) or from a negative effect of extracellular formation of ice on the phenolic metabolism of Sphagnum (Solecka and Kacperska, 2003). Reduced water-soluble phenolics were related to lower testate amoeba biomass but also to the lower mean size of the community (e.g. lower body length, pseudostome size and biovolume). This suggests that decreasing phenolic concentrations with decreasing temperatures can alter microbial assemblages in peatlands, as showed with summer warming (Jassey et al., 2013a), and even select for specific microbial functional groups (Hättenschwiler and Vitousek, 2000). These results are consistent with previous findings from tundra soils reporting shifts in phenolic-microbial interactions in freezing soils (Schmidt and Lipson, 2004). Overall, our findings showed that exposure to harder frost events significantly influence the forces structuring microbial communities in peatlands. Such community response is expected to have significant consequences on ecosystem functioning as suggested by 
the shifts in functional diversity.

\section{Ecosystem consequences}

Our enzymatic assays partly confirmed previous observations that freezing reduces microbial activity in carbon-rich soils (Hartley et al., 2008). Temperature and precipitation are among the key factors controlling microbial activity involved in C cycling in peatlands (Bragazza et al., 2013), and our results support these findings. However, our results also support the hypothesis that such decreases in microbial activity are the result of functional shifts within higher trophic level, i.e. the testate amoebae. As showed for plant functional diversity (Robroek et al., 2015; Steinauer et al., 2015), our findings revealed that $\beta$-glucosidase enzymatic activity strongly depended of functional composition and turnover of testate amoebae. This indicates that species replacement within testate amoeba community along the climatic gradient was accompanied by a functional replacement, which strongly determines microbial activity involved in $\mathrm{C}$ cycle. This result is particularly significant given the shifts in CWM traits of testate amoebae. Indeed, we found that exposure to harder frost events and reduced precipitation was accompanied by a replacement of large testate amoeba species by the small-body mixotrophic species Archerella flavum.

Increasing abundance of mixotrophic species can potentially affect $\mathrm{C}$ dynamics of ecosystems (Mitra et al., 2013). As phototrophs, mixotrophic testate amoebae can contribute to photosynthetic C fixation (Jassey et al., 2015), whilst as bacterial/fungal grazers (Jassey et al., 2013b) they can influence organic matter decomposition by controlling bacterial and fungal populations. Hence, higher mixotroph densities can either increase $\mathrm{C}$ uptake or $\mathrm{C}$ release in peatlands, depending on the relative contribution of phototrophy and heterotrophy in their feeding behaviour. As supported by stable isotope analyses (Jassey et al., 2013b; Mieczan et al., 2015a), mixotrophic testate amoebae mainly acquire their total $C$ through photosynthesis. Consequently, a decrease of the dominance of mixotrophic testate amoebae means that less $\mathrm{C}$ is stored by the system and more space is available for strict bacterivores and/or fungivores in the community, as observed in Clara bog with the high abundances of Phryganella sps. and Hyalosphenia elegans species. Intensified bacterial grazing by protists is known to enhance microbial turnover (Bonkowski, 2004), leading to an overall increased microbial activity (Jílková et al., 2015), which can then cascade to 
heterotrophic respiration and nutrient cycling (Petersen and Luxton, 1982). The link we found between the functional diversity of testate amoebae and $\beta$-glucosidase activity tends to support such hypothesis and suggest that the shift in the functional structure of testate amoebae promotes microbial activity involved in C cycle. Further experimental work is however needed to fully distinguish whether changes in climatic conditions directly impact microbial activity or indirectly affect activity by shifting species composition.

With current winter climate warming, snow cover will continue to become thinner, and of shorter duration, increasing the exposure of soils to harder frost events. Our findings indicate that exposure to hard soil frost negatively impacts on testate amoeba function and, consequently, on soil microbial activity. Considering that freeze/thaw cycles are expected to increase in the coming decades (Groffman et al., 2001), the associated effects on microbial activity could be rather important for the overall C balance in peatlands (Robroek et al., 2013). Understanding the mechanistic links that shape thermal tolerance of large individuals clearly needs further experimentation and would greatly improve our ability to predict species response to climate changes, and ecosystem processes.

\section{Acknowledgements}

This research has been funded by the Swiss National Science Foundation through the project SPHAGNOL (grant number: 315260_149807 to LB). This research was also supported by the grant PSPB-013/2010 from Switzerland through the Swiss Contribution to the enlarged European Union. 


\section{References}

Bale, J.S., 2002. Insects and low temperatures: from molecular biology to distributions and abundance. Philos. T. R. Soc. B. 357, 849-862.

Baselga, A., 2010. Partitioning the turnover and nestedness components of beta diversity. Glob. Ecol. Biogeogr. 19, 134-143. doi:10.1111/j.1466-8238.2009.00490.x

Baselga, A., Orme, C.D.L., 2012. betapart: an R package for the study of beta diversity. Methods Ecol. Evol. 3, 808-812.

Beyens, L., 1989. Moss dwelling diatom assemblages from Edgeøya (Svalbard). Polar Biol. 9, 423-430.

Beyens, L., Chardez, D., De Landtsheer, R., De Bock, P., Jacques, E., 1986. Testate amoebae populations from moss and lichen habitats in the Arctic. Polar Biol. 5, 165-173.

Bjerke, J. W., Bokhorst, S., Zielke, M., Callaghan, T. V., Bowles, F. W., Phoenix, G. K. 2011. Contrasting sensitivity to extreme winter warming events of dominant sub-Arctic heathland bryophyte and lichen species. J. Ecol., 99(6), 1481-1488.

Bjerke, J. W., Bokhorst, S., Callaghan, T. V. 2013. Rapid photosynthetic recovery of a snowcovered feather moss and Peltigera lichen during sub-Arctic midwinter warming. Plant Ecol. Div., 6, 383-392.

Bokhorst, S., Bjerke, J.W., Bowles, F.W., Melillo, J., Callaghan, T.V., Phoenix, G.K., 2008. Impacts of extreme winter warming in the sub- Arctic: growing season responses of dwarf shrub heathland. Glob. Change Biol. 14, 2603-2612.

Bokhorst, S., Bjerke, J.W., Melillo, J., Callaghan, T.V., Phoenix, G.K., 2010. Impacts of extreme winter warming events on litter decomposition in a sub-Arctic heathland. Soil Biol.Biochem. 42, 611-617. doi:10.1016/j.soilbio.2009.12.011

Bokhorst, S., Phoenix, G.K., Berg, M.P., Callaghan, T.V., Kirby-Lambert, C., Bjerke, J.W., 2015. Climatic and biotic extreme events moderate long-term responses of above- and belowground sub-Arctic heathland communities to climate change. Glob Change Biol. n/a-n/a.

Bokhorst, S., Phoenix, G.K., Bjerke, J.W., Callaghan, T.V., Huyer Brugman, F., Berg, M.P., 2012. Extreme winter warming events more negatively impact small rather than large soil fauna: shift in community composition explained by traits not taxa. Glob Change Biol. 18, 1152-1162.

Bokhorst, S.F., Bjerke, J.W., Tømmervik, H., Callaghan, T.V., Phoenix, G.K., 2009. Winter warming events damage sub- Arctic vegetation: consistent evidence from an experimental manipulation and a natural event. J. Ecol. 97, 1408-1415.

Bonkowski, M., 2004. Protozoa and plant growth: the microbial loop in soil revisited. New Phytol. 162, 617-631.

Borcard, D., Gillet, F., Legendre, P., 2011. Numerical Ecology with R. Springer, New York. Bragazza, L., Parisod, J., Buttler, A., Bardgett, R.D., 2013. Biogeochemical plant-soil microbe feedback in response to climate warming in peatlands. Nat. Clim. Change 3, 273-277. Cannon, R.J.C., Block, W., 1988. Cold Tolerance of Microarthropods. Biol. Rev. 63, 23-77. 
Carpenter, S.R., Kitchell, J.F., 1988. Consumer Control of Lake Productivity. BioScience 38, 764769.

Cornelissen, J.H.C., Makoto, K., 2014. Winter climate change, plant traits and nutrient and carbon cycling in cold biomes. Ecol. Res. 29, 517-527.

Dixon, R., Paiva, N.L., 1995. Stress-Induced Phenylpropanoid Metabolism. Plant Cell 7, 10851097.

Durán, J., Morse, J.L., Groffman, P.M., Campbell, J.L., Christenson, L.M., Driscoll, C.T., Fahey, T.J., Fisk, M.C., Mitchell, M.J., Templer, P.H., 2014. Winter climate change affects growing- season soil microbial biomass and activity in northern hardwood forests. Glob. Change Biol. 20, 3568-3577.

Durán, J., Rodríguez, A., Morse, J.L., Groffman, P.M., 2013. Winter climate change effects on soil $\mathrm{C}$ and $\mathrm{N}$ cycles in urban grasslands. Glob. Change Biol. 19, 2826-2837.

Fonseca, C.R., Ganade, G., 2001. Species functional redundancy, random extinctions and the stability of ecosystems. J. Ecol. 89, 118-125.

Garnier, E., Lavorel, S., Ansquer, P., Castro, H., Cruz, P., Dolezal, J., Eriksson, O., Fortunel, C., Freitas, H., Golodets, C., Grigulis, K., Jouany, C., Kazakou, E., Kigel, J., Kleyer, M., Lehsten, V., Leps, J., Meier, T., Pakeman, R., Papadimitriou, M., Papanastasis, V.P., Quested, H., Quétier, F., Robson, M., Roumet, C., Rusch, G., Skarpe, C., Sternberg, M., Theau, J.-P., Thébault, A., Vile, D., Zarovali, M.P., 2007. Assessing the effects of land-use change on plant traits, communities and ecosystem functioning in grasslands: a standardized methodology and lessons from an application to 11 European sites. Ann. Bot. 99, 967-985.

Gilbert, D., Amblard, C., Bourdier, G., Francez, A., 1998. The Microbial Loop at the Surface of a Peatland: Structure, Function, and Impact of Nutrient Input. Microb. Ecol. 35, 83-93.

Gilbert, D., Mitchell, E.A.D., Amblard, C., Bourdier, G., Francez, A.-J., 2003. Population dynamics and food preferences of the testate amoeba Nebela tincta major-bohemica-collaris complex (Protozoa) in a Sphagnum peatland. Acta protozoo. 42, 99-104.

Groffman, P.M., Driscoll, C.T., Fahey, T.J., Hardy, J.P., Fitzhugh, R.D., Tierney, G.L., 2001. Colder soils in a warmer world: A snow manipulation study in a northern hardwood forest ecosystem. Biogeochem. 56, 135-150.

Hartley, I.P., Hopkins, D.W., Garnett, M.H., Sommerkorn, M., Wookey, P.A., 2008. Soil microbial respiration in arctic soil does not acclimate to temperature. Ecol. Lett. 11, 1092-1100.

Hättenschwiler, S., Vitousek, P.M., 2000. The role of polyphenols in terrestrial ecosystem nutrient cycling. Trends Ecol. Evol. 15, 238-243.

Hijmans, R.J., Cameron, S.E., Parra, J.L., Jones, P.G., Jarvis, A., 2005. Very high resolution interpolated climate surfaces for global land areas. Int. J. Climatol. 25, 1965-1978.

Hollesen, J., Buchwal, A., Rachlewicz, G., Hansen, B.U., Hansen, M.O., Stecher, O., Elberling, B., 2015. Winter warming as an important co-driver for Betula nana growth in western Greenland during the past century. Glob. Change Biol. 21, 2410-2423. 
Hooper, D.U., Adair, E.C., Cardinale, B.J., Byrnes, J.E.K., Hungate, B.A., Matulich, K.L., Gonzalez, A., Duffy, J.E., Gamfeldt, L., O'Connor, M.I., 2013. A global synthesis reveals biodiversity loss as a major driver of ecosystem change. Nature 486, 105-108.

Jassey, V.E.J., Chiapusio, G., Binet, P., Buttler, A., Laggoun-Défarge, F., Delarue, F., Bernard, N., Mitchell, E.A.D., Toussaint, M.-L., Francez, A.-J., Gilbert, D., 2013a. Above- and belowground linkages in Sphagnum peatland: climate warming affects plant-microbial interactions. Glob. Change Biol. 19, 811-823.

Jassey, V.E.J., Chiapusio, G., Gilbert, D., Buttler, A., Toussaint, M.-L., Binet, P., 2011 a.

Experimental climate effect on seasonal variability of polyphenol/phenoloxidase interplay along a narrow fen-bog ecological gradient in Sphagnum fallax. Glob. Change Biol. 17, 2945-2957.

Jassey, V.E.J., Chiapusio, G., Mitchell, E.A.D., Binet, P., Toussaint, M.-L., Gilbert, D., 2011b. Finescale horizontal and vertical micro-distribution patterns of testate amoebae along a narrow Fen/Bog gradient. Microb. Eol. 61, 374-385.

Jassey, V.E.J., Lamentowicz, Ł., Robroek, B.J.M., Gabka, M., Rusińska, A., Lamentowicz, M., 2014. Plant functional diversity drives niche- size- structure of dominant microbial consumers along a poor to extremely rich fen gradient. J. Ecol. 102, 1150-1162.

Jassey, V.E.J., Meyer, C., Dupuy, C., Bernard, N., Mitchell, E.A.D., Toussaint, M.-L., Metian, M., Chatelain, A.P., Gilbert, D., 2013b. To What Extent Do Food Preferences Explain the Trophic Position of Heterotrophic and Mixotrophic Microbial Consumers in a Sphagnum Peatland? Microb. Ecol. 66, 571-580.

Jassey, V.E.J., Shimano, S., Dupuy, C., Toussaint, M.-L., Gilbert, D., 2012. Characterizing the feeding habits of the testate amoebae Hyalosphenia papilio and Nebela tincta along a narrow "fen-bog" gradient using digestive vacuole content and $13 \mathrm{C}$ and $15 \mathrm{~N}$ isotopic analyses. Protist 163, 451-464.

Jassey, V.E.J., Signarbieux, C., Hättenschwiler, S., Bragazza, L., Buttler, A., Delarue, F., Fournier, B., Gilbert, D., Laggoun-Défarge, F., Lara, E., Mills, R.T.E., Mitchell, E.A.D., Payne, R.J., Robroek, B.J.M., 2015. An unexpected role for mixotrophs in the response of peatland carbon cycling to climate warming. Sci. Rep. 5, 16931.

Jílková, V., Frouz, J., Cajthaml, T., Bonkowski, M., 2015. The role of bacteria and protists in nitrogen turnover in ant nest and forest floor material: A laboratory experiment. Eur. J. Soil Biol. 69, 66-73.

Konestabo, H.S., Michelsen, A., Holmstrup, M., 2007. Responses of springtail and mite populations to prolonged periods of soil freeze-thaw cycles in a sub-arctic ecosystem. App. Soil Ecol. 36, 136-146.

Krashevska, V., Sandmann, D., Maraun, M., Scheu, S., 2014. Moderate changes in nutrient input alter tropical microbial and protist communities and belowground linkages. ISME J. 8, 11261134.

Kreyling, J. 2010. Winter climate change: a critical factor for temperate vegetation performance. 
Ecology, 91, 1939-1948.

Kreyling, J., Jurasinski, G., Grant, K., Retzer, V., Jentsch, A., Beierkuhnlein, C. 2011. Winter warming pulses affect the development of planted temperate grassland and dwarf-shrub heath communities. Plant Ecol. Div. 4, 13-21.

Lamentowicz, M., Bragazza, L., Buttler, A., Jassey, V.E.J., Mitchell, E.A.D., 2013. Seasonal patterns of testate amoeba diversity, community structure and species-environment relationships in four Sphagnum-dominated peatlands along a $1300 \mathrm{~m}$ altitudinal gradient. Soil Biol. Biochem. 67, 1-11.

Laminger, H., 1978. The Effects of Soil Moisture Fluctuations on the Testacean Species Trinema enchelys (Ehrenberg) Leidy in a High Mountain Brown-earths-podsol and its Feeding Behaviour. Archiv für Protistenkunde 120, 446-454.

Ledeganck, P., Nijs, I., Beyens, L., 2003. Plant functional group diversity promotes soil protist diversity. Protist 154, 239-249.

Legendre, P., 1993. Spatial autocorrelation: trouble or new paradigm? Ecology 74, 1659-1673. Legendre, P., Gallagher, E.D., 2001. Ecologically meaningful transformations for ordination of species data. Oecologia 129, 271-280.

Lousier, J.D., Parkinson, D., 1984. Annual population dynamics and production ecology of Testacea (Protozoa, Rhizopoda) in an aspen woodland soil. Soil Biol. Biochem. 16, 103-114. Makoto, K., Kajimoto, T., Koyama, L., Kudo, G., Shibata, H., Yanai, Y., Cornelissen, J.H.C., 2014. Winter climate change in plant-soil systems: summary of recent findings and future perspectives. Ecol. Res. 29, 593-606.

Martz, F., Peltola, R., Fontanay, S., Duval, R.E., Julkunen-Tiitto, R., Stark, S., 2009. Effect of Latitude and Altitude on the Terpenoid and Soluble Phenolic Composition of Juniper (Juniperus communis) Needles and Evaluation of Their Antibacterial Activity in the Boreal Zone. J. Agric. Food Chem. 57, 9575-9584.

Mieczan, T., Michał, N., Adamczuk, M., Bielańska Grajner, I., 2015a. Stable isotope analyses revealed high seasonal dynamics in the food web structure of a peatbog. Int. Rev. Hydro. 100, 1-10.

Mieczan, T., Niedźwiecki, M., Tarkowska-Kukuryk, M., 2015b. Effects of rotifers, copepods and chironomid larvae on microbial communities in peatlands. Eur. J. Protistol. 51, 386-400.

Milcu, A., Roscher, C., Gessler, A., Bachmann, D., Gockele, A., Guderle, M., Landais, D., Piel, C., Escape, C., Devidal, S., Ravel, O., Buchmann, N., Gleixner, G., Hildebrandt, A., Roy, J., 2014. Functional diversity of leaf nitrogen concentrations drives grassland carbon fluxes. Ecol. Lett. 17, 435-444.

Mitchell, E.A.D., Borcard, D., Buttler, A.J., Grosvernier, P., Gilbert, D., Gobat, J.M., 2000. Horizontal Distribution Patterns of Testate Amoebae (Protozoa) in a Sphagnum magellanicum Carpet. Microb. Ecol. 39, 290-300.

Mitra, A., Flynn, K.J., Burkholder, J.M., Berge, T., Calbet, A., Raven, J.A., Granéli, E., Glibert, 
P.M., Hansen, P.J., Stoecker, D.K., Thingstad, F., Tillmann, U., Våge, S., Wilken, S., Zubkov, M.V., 2013. The role of mixotrophic protists in the biological carbon pump. Biogeosciences

Discuss. 10, 13535-13562.

Oksanen, J., 2011. Multivariate analysis of ecological communities in R: vegan tutorial. R package version.

Payne, R.J., Mitchell, E.A.D., 2009. How many is enough? Determining optimal count totals for ecological and palaeoecological studies of testate amoebae. J. Paleolimn. 42, 483-495.

Perkins, D.M., Bailey, R.A., Dossena, M., Gamfeldt, L., Reiss, J., Trimmer, M., Woodward, G., 2015. Higher biodiversity is required to sustain multiple ecosystem processes across temperature regimes. Glob. Change Biol. 21, 396-406.

Petersen, H., Luxton, M., 1982. A Comparative Analysis of Soil Fauna Populations and Their Role in Decomposition Processes. Oikos 39, 288.

Pinheiro, J.C., Bates, D.M., 2000. Linear Mixed-Effects Models: Basic Concepts and Examples, in: Mixed-Effects Models in Sand S-PLUS. Springer New York, pp. 3-56.

R Core Team, 2013. R: A language and environment for statistical computing. R Foundation for Statistical Computing, Vienna, Austria.

Ricotta, C., 2005. A note on functional diversity measures. Basic Appl. Ecol. 6, 479-486.

Robroek, B.J.M., Albrecht, R.J.H., Hamard, S., Pulgarin, A., Bragazza, L., Buttler, A., Jassey, V.E.J., 2015. Peatland vascular plant functional types affect dissolved organic matter chemistry. Plant Soil, in press.

Robroek, B.J.M., Heijboer, A., Jassey, V.E.J., Hefting, M.M., Rouwenhorst, T.G., Buttler, A., Bragazza, L., 2013. Snow cover manipulation effects on microbial community structure and soil chemistry in a mountain bog. Plant Soil 369, 151-164.

Robroek, B.J.M., Jassey, V.E.J., Kox, M., Berendsen, R.L., Mills, R.T.E., Cécillon, L., Puissant, J., Meima-Franke, M., Bakker, P.A.H.M., Bodelier, P.L.E. (2015). Peatland vascular plant functional types affect methane dynamics by altering microbial community structure. J. Ecol. 103, 925-934.

Schmidt, S.K., Lipson, D.A., 2004. Microbial growth under the snow: Implications for nutrient and allelochemical availability in temperate soils. Plant Soil 259, 1-7.

Solecka, D., Kacperska, A., 2003. Phenylpropanoid deficiency affects the course of plant acclimation to cold. Physiol Plant. 119, 253-262.

Steinauer, K., Tilman, D., Wragg, P.D., Cesarz, S., Cowles, J.M., Pritsch, K., Reich, P.B., Weisser, W.W., Eisenhauer, N., 2015. Plant diversity effects on soil microbial functions and enzymes are stronger than warming in a grassland experiment. Ecology 96, 99-112.

Stocker, T., Qin, D., Plattner, G.K., Tignor, M., Allen, S.K., 2014. Climate change 2013: The physical science basis. Contribution of Working Group I to the Fifth Assessment Report of the Intergovernmental Panel on Climate Change (Cambridge Univ. Press, Cambridge/New York). Sømme, L., 1982. Supercooling and winter survival in terrestrial arthropods. Comp. Biochem. 
Physiol. 73, 519-543.

Tsyganov, A.N., Temmerman, S., Ledeganck, P., Beyens, L., 2012. The Distribution of Soil Testate Amoebae under Winter Snow Cover at the Plot-scale Level in Arctic Tundra (Qeqertarsuaq/Disko Island, West Greenland). Acta protozool. 51, 155-167.

Utermolh, H., 1958. Zur vervollkommnung der quantative phytoplankton-methodik. Mitteilungen aus Institut Verhein Limnologie 9, 1-38.

Villéger, S., Grenouillet, G., Brosse, S., 2013. Decomposing functional $\beta$-diversity reveals that low functional $\beta$-diversity is driven by low functional turnover in European fish assemblages. Global Ecol. Biogeogr. 22, 671-681.

Villéger, S., Mason, N.W.H., Mouillot, D., 2008. New multidimensional functional diversity indices for a multifaceted framework in functional ecology. Ecology 89, 2290-2301.

Villéger, S., Novack-Gottshall, P.M., Mouillot, D., 2011. The multidimensionality of the niche reveals functional diversity changes in benthic marine biotas across geological time. Ecol. Lett. 14, 561-568.

Vincke, S., Gremmen, N., Beyens, L., Van de Vijver, B., 2004. The moss dwelling testacean fauna of Île de la Possession. Polar Biol. 27, 753-766.

Wagner, H.H., 2004. Direct multi-scale ordination with canonical correspondence analysis. Ecology 85, 342-351.

Weedon, J.T., Aerts, R., Kowalchuk, G.A., van Bodegom, P.M., 2014. No effects of experimental warming but contrasting seasonal patterns for soil peptidase and glycosidase enzymes in a sub-arctic peat bog. Biogeochem. 117, 55-66.

Wilkinson, D.M., Mitchell, E.A.D., 2010. Testate amoebae and nutrient cycling with particular reference to soils. Geomicrobiol. J. 27, 520-533. 


\section{Figure captions}

Figure 1: Map of Europe showing the location of the four peatlands and the magnitude of main climatic variables. Forb: Forbonnet; Kus: Kusowo; SM: Store Mosse. Dot size represents the winter dissimilarity among sites with Kusowo as a reference (highest longitude). Minimum air temperature, mean winter air and soil temperatures, precipitations and snow height plotted against longitude (mean \pm SD; data from beginning of January to mid-February).

Figure 2: (A) Redundancy analysis biplot of Hellinger-transformed testate amoeba communities constrained by snow cover depth, minimum winter air temperature (TMIN), precipitations during winter (Wprec) and water-soluble polyphenols (phenols). Only species with abundance $>3 \%$ are shown. (B) Redundancy analysis biplot of standardized CWM traits of testate amoebae constrained by snow cover depth and minimum winter air temperature (TMIN). All axes are significant at ${ }^{* *} P<0.01$ and all explanatory variables were significant at $P<0.05$ (permutation tests). Species abbreviations: afla: Archerella flavum; amusc: Assulina muscorum; asem: Assulina seminulum; cenlae: Centropyix laevigata; cordub: Corythion dubium; cryovi: Cryptodifflugia oviformis type; eugcomp: Euglypha compressa; eugstri: Euglypha strigosa; helpet: Heleopera petricola; helros: Heleopera rosea; helsph: Heleopera sphagni; helsyl: Heleopera sylvatica; hyael: Hyalosphenia elegans; hyapap: Hyalosphenia papilio; nebcol: Nebela collaris; nebflab: Nebela flabellulum; nebmil: Nebela militaris; nebtin: Nebela tincta; phryacro: Phryganella acropodia; phrydiss: Phryganella dissimulatoris type.

Figure 3: Relative contribution of turnover (A) and nestedness-resultant $(B)$ components to taxonomic and functional $\beta$-diversity. $r$ is the correlation coefficient from linear model. Response of $\beta$-diversity (community dissimilarity) (C) and functional $\beta$-diversity (functional dissimilarity) (D), and their related turnover components $(E, F)$, to changing winter conditions (winter conditions dissimilarity). $r$ is the Pearson's coefficient from Mantel tests. 
Figure 4: Relationship between functional alpha $(A)$ and beta $(B)$ diversity of testate amoebae and $\beta$-glucosidase enzymatic activity (mean \pm SEM) in the four European peat bogs. Dot size on lower plot show the average abundance of mixotrophic testate amoebae. $R^{2}$ is adjusted R-squared from linear models. 

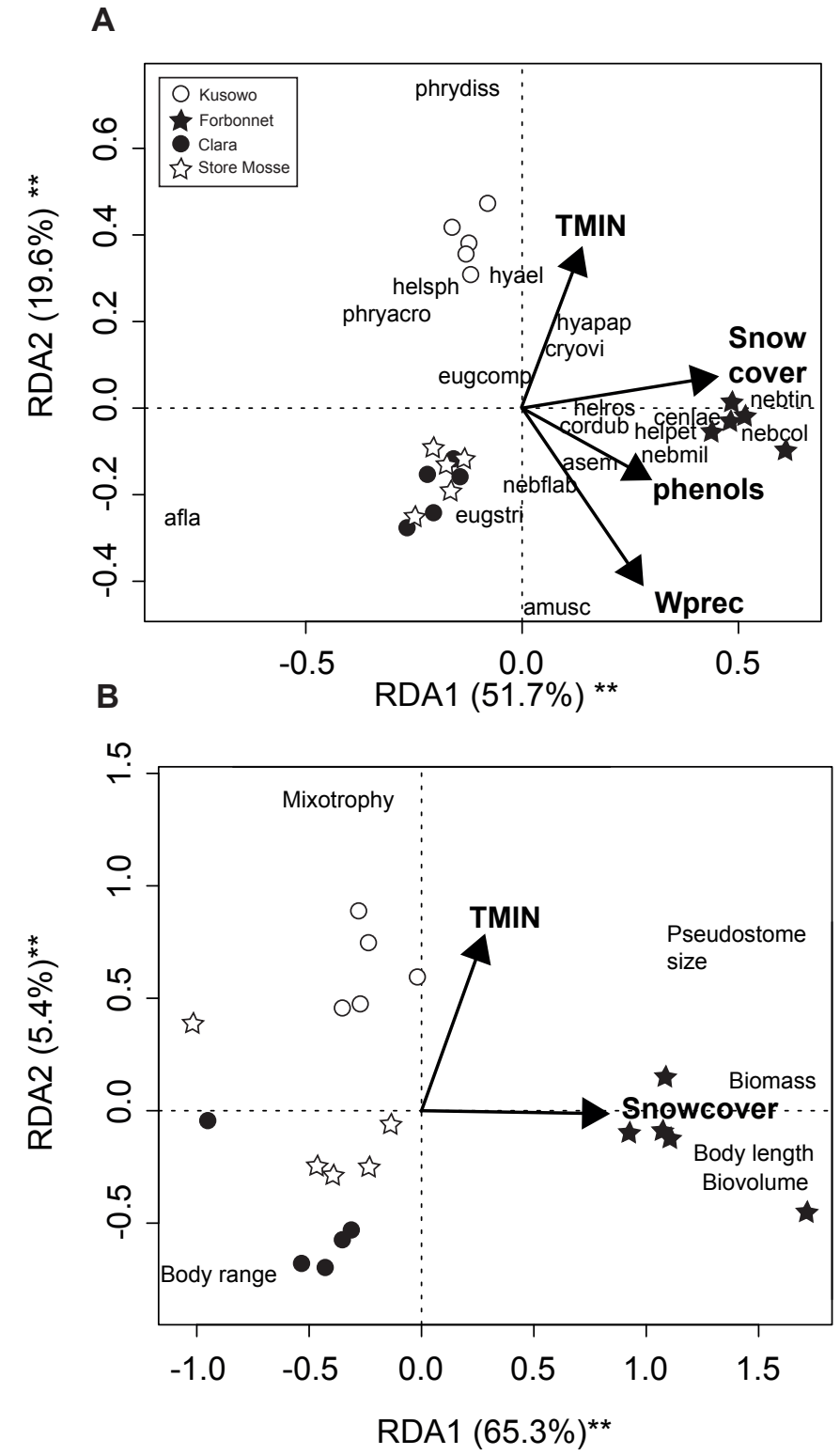


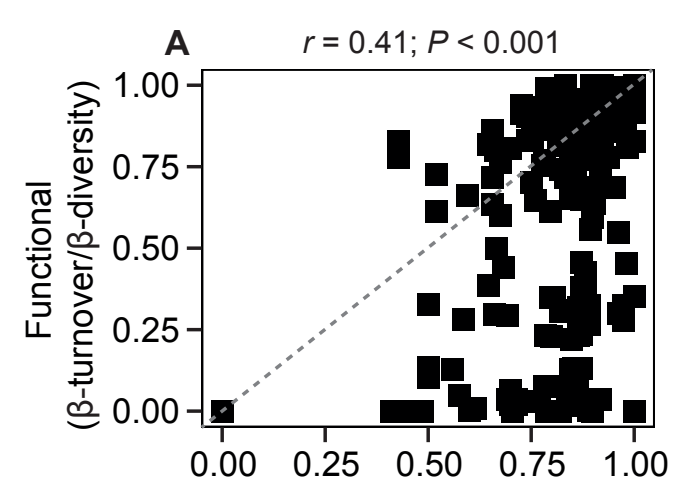

Taxonomic

( $\beta$-turnover/ $\beta$-diversity)

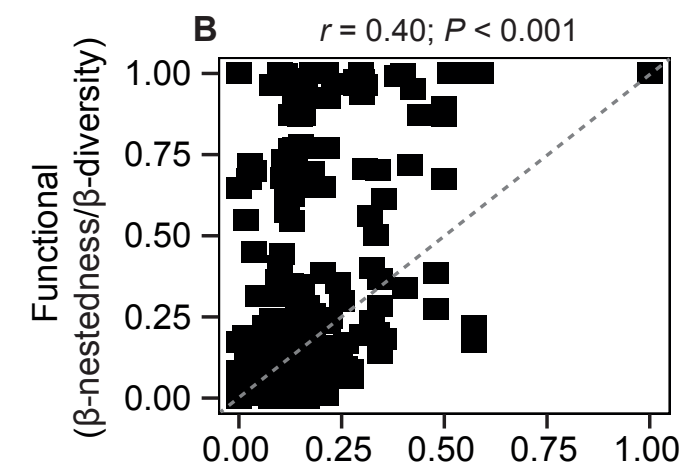

Taxonomic

( $\beta$-nestedness/ $\beta$-diversity)
C $\quad r=0.64 ; P<0.001$

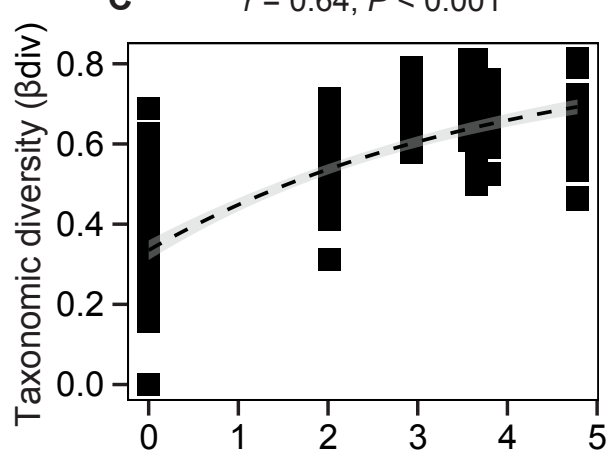

Winter climatic dissimilarity

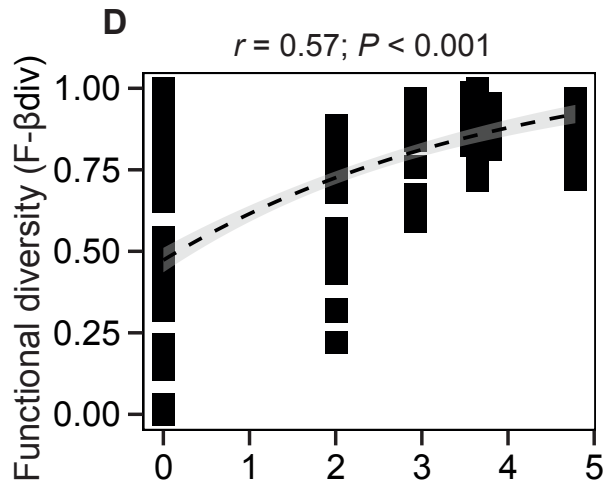

Winter climatic dissimilarity

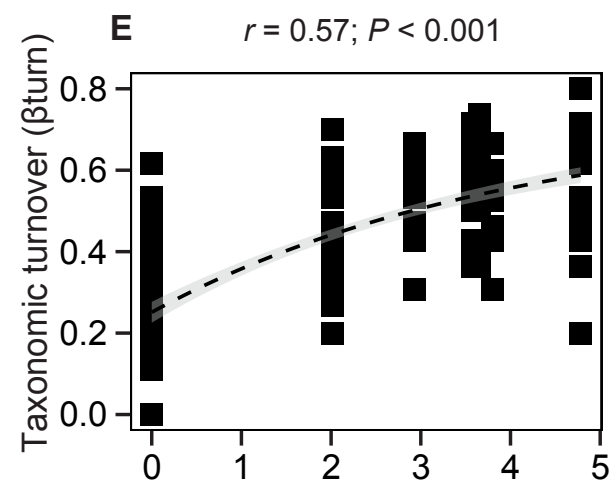

Winter climatic dissimilarity

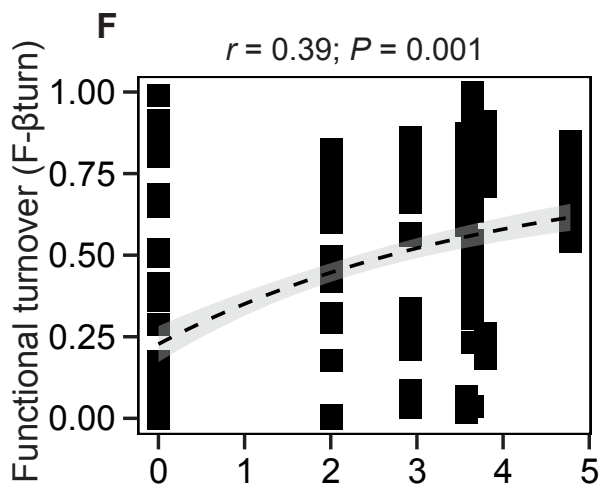

Winter climatic dissimilarity 


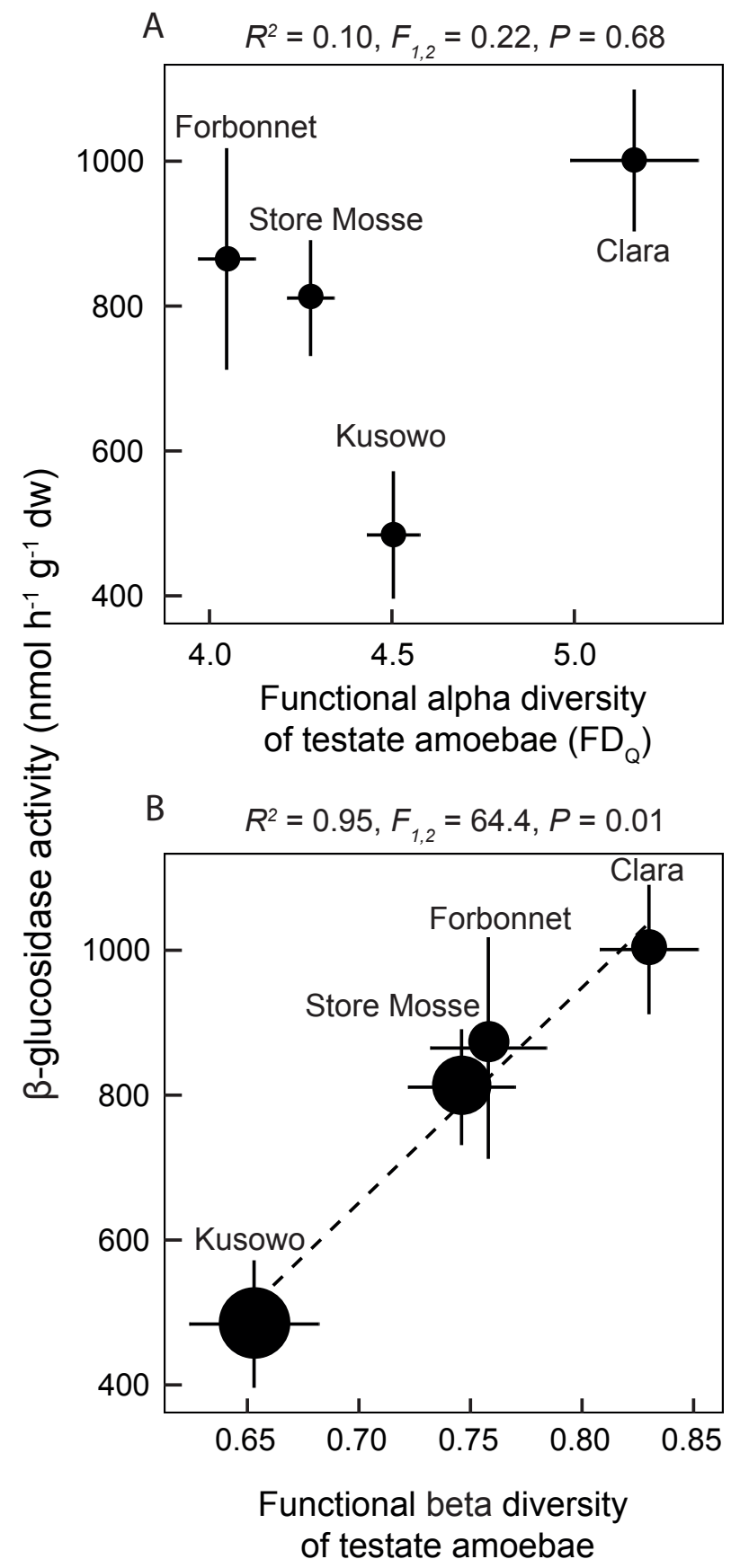


Table 1: Key ecological traits of testate amoebae and related hypotheses on how they might respond to winter climate

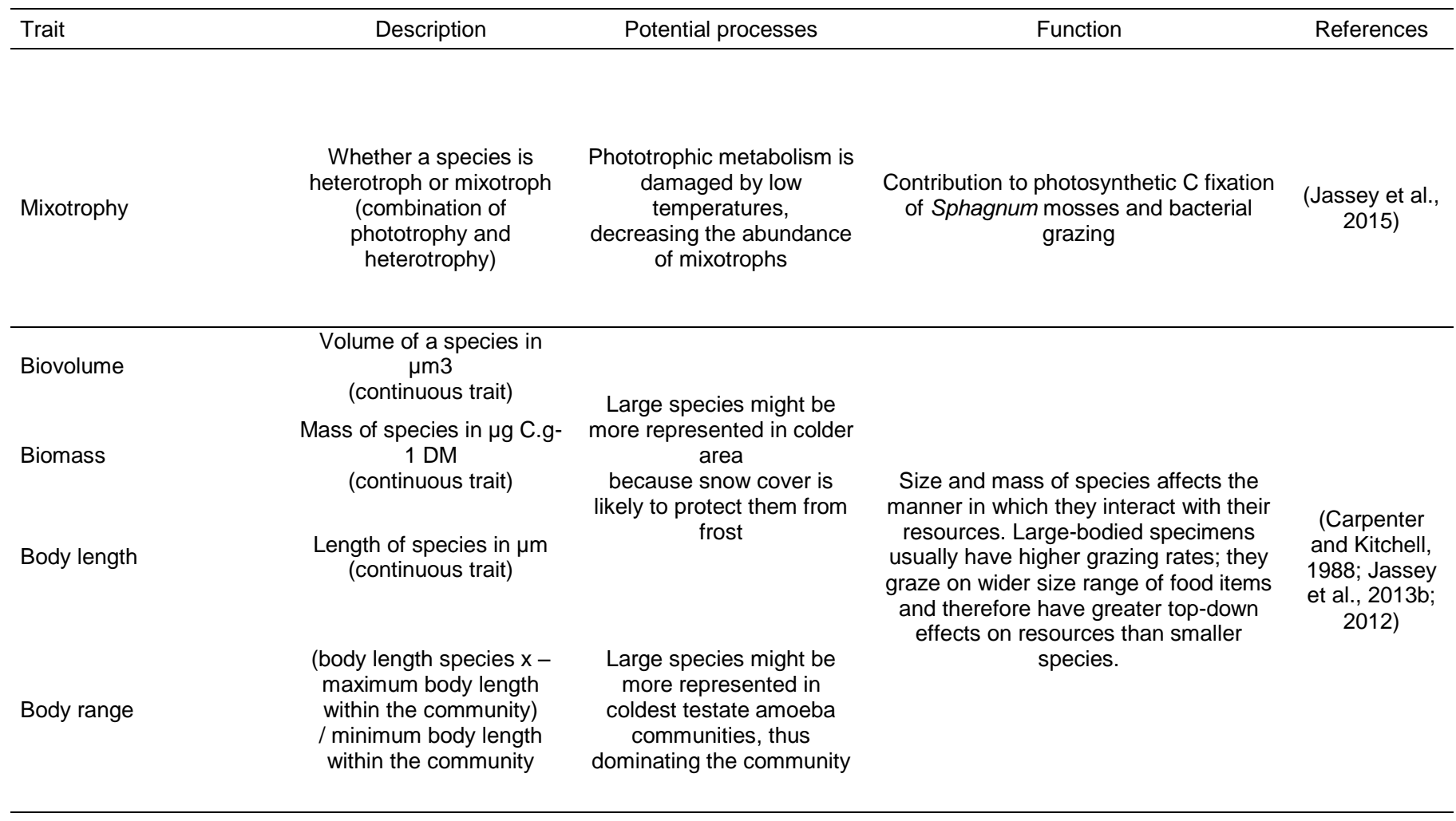

Pseudostome size (shell aperture size)

\section{Size of the pseudostome$$
\text { in } u \text { m }
$$

(continuous trait)
Two species with equal body length but different pseudostome size may differently respond to frost
Species with large pseudostome are likely to feed on a wider size range of (Jassey et al., down effects on resources than smaller 2013b)

$$
\text { species. }
$$


Table 2: Mean $( \pm$ SE) of water-soluble phenolic compounds of Sphagnum magellanicum at the four peatlands. Mean ( \pm SE) of potential activity of $\beta$-glucosidase, alanine peptidase and phosphatase in the different peatlands. Letters indicate significant differences among sites $(P<0.05$, ANOVA); $N=5$ per site.

\begin{tabular}{lllll}
\hline & Clara & Forbonnet & Kusowo & Store Mosse \\
\hline $\begin{array}{l}\text { Sphagnum chemistry } \\
\text { Phenols }\left(\mathrm{mg} \cdot \mathrm{g}^{-1} \mathrm{dw}\right)\end{array}$ & $1.08(0.03) \mathrm{ab}$ & $1.24(0.09) \mathrm{b}$ & $0.90(0.05) \mathrm{a}$ & $0.90(0.05) \mathrm{a}$ \\
$\begin{array}{l}\text { Enzymatic activities } \\
\beta-\text { glucosidase }\left(\mathrm{nmol} \cdot \mathrm{h}^{-1} \cdot \mathrm{g}^{-1} \mathrm{dw}\right)\end{array}$ & $1001(98) \mathrm{c}$ & $865(153) \mathrm{b}$ & $484(88) \mathrm{a}$ & $811(80) \mathrm{b}$ \\
Alanine peptidase $\left(\mathrm{nmol}^{-1} \cdot \mathrm{g}^{-1} \mathrm{dw}\right)$ & $716(104) \mathrm{a}$ & $793(151) \mathrm{a}$ & $666(81) \mathrm{a}$ & $600(51) \mathrm{a}$ \\
Phosphatase $\left(\mathrm{nmol} \cdot \mathrm{h}^{-1} \cdot \mathrm{g}^{-1} \mathrm{dw}\right)$ & $4642(677) \mathrm{a}$ & $3586(924) \mathrm{a}$ & $3214(770) \mathrm{a}$ & $4926(538) \mathrm{a}$ \\
\hline
\end{tabular}

